9. Karlin, T. P. Analiz finansovyh otchetov (na osnove GAAP) [Text] / T. P. Karlin, A. R. Makmin. - Moscow: Delo, 1998. - 448 p.

10. Kovalev, V. V. Finansovyi analiz [Text] / V. V. Kovalev. Moscow: Finansy i statistika, 1997. - 450 p.

11. Savchuk, V. P. Finansovyi menedzhment predpriiatii [Text] V. P. Savchuk. - Kyiv: Izdatel'skii dom «Maksimum», 2001. - 600 p.

12. Savchuk, V. Analiz i razrabotka investitsionnyh proektov [Text] V. Savchuk, S. Prilipko, E. Velichko. - Kyiv: Absoliut-V, 1999. -450 p.

\section{АНАЛИЗ И ОЦЕНКА ЗФФЕКТИВНОСТИ ИНВЕСТИЦИОННЫХ IPOEKTOB}

Проведен анализ развития инвестиционных проектов в $\mathrm{У}_{\text {- }}$ раине. Представлена общая характеристика международной практики существующих методов оценки эффективности инвестиционных проектов/программ. Представлено обоснование целесообразности принятия инвестиционных решений относительно выбранных проектов/программ. Представлены этапы разработки и внедрения инвест-проекта/программы, а именно: организационно-подготовительный этап; этап непосредственной разработки проекта/программы; этап согласования и утверждения проекта/программы; этап пропаганды проекта/программы и контроля за его выполнением.

Ключевые слова: инвест-проекты, методы оценки эффективности инвест-проектов, этапы разработки инвест-проектов/программ.

Lemeshko Nataliia, Department of Economics and Entrepreneur ship, National Technical University of Ukraine «Igor Sikorsky Kyiz Polytechnic Institute», Ukraine, e-mail: klimchuk.irina@gmail.com, ORCID: http://orcid.org/0000-0002-9783-2393
Sharko M.,

Burenko J.,

Gusarina $\mathbf{N}$.

\title{
MODELING OF MANAGEMENT OF THE INFORMATION POTENTIAL OF COMPLEX ECONOMIC SYSTEMS UNDER CONDITIONS OF RISK
}

Проведено інформащійний аналіз і синтез прочесів, що відбуваються в складних економічних системах, що характеризуються різноманіттям варіантів структури відносин. Розглянуто структуру управління ієрархічними системами з використанням лінгвістичного, евристичного, інформаційного і математичного підходів. Представлена структурно-функціональна послідовність операщій управління з урахуванням обмежень на ресурси і впливів зовнішнього середовища.

Ключові слова: економічні системи, управління інформаційними можливостями, умови ризику, інформаційний потенціал.

\section{Introduction}

In modern conditions of functioning of complex economic systems, modeling is the main stage of system analysis of production and socio-economic systems and an urgent problem for each enterprise. Along with widespread simulation for solving management problems, structural and functional modeling of analysis and synthesis of complex systems using computer models begins to be used. Difficulties in solving the problems of managing economic systems under conditions of uncertainty of the influence of the external environment and risk are determined by both the large dimension of the control actions and the dimensionality of the system of constraints.

To form an effective strategy for managing economic systems under conditions of risk, it is necessary to correctly use the information potential of enterprises on the basis of analysis and synthesis of methods for modeling complex economic systems.

\section{The object of research and its technological audit}

With the purpose of effective use of the information potential of the enterprise, a study of the scientific and methodological foundations of managing complex multilevel economic systems under conditions of uncertainty and risk has been carried out. The essence of information analysis of processes occurring in economic systems is the collection of necessary information, its exchange with subsystems, analysis, processing and its use [1]. The task of information synthesis includes justification of the necessary volume, forms of information, methods and means of its processing and storage [2]. Both these areas of studying information processes occurring in economic systems are an effective tool for studying complex economic systems [3-5].

Complex production systems are characterized by such features as the presence of a large number of interconnected subsystems and elements, multidimensionality, due to the large number of connections between the elements, the diversity of the objectives of the subsystems, multifunctionality, and the variety of structure options. In most cases, the structure of interactions between the elements of the system is hierarchical [6].

The difference between hierarchical and centralized systems is that for systems with centralized control there is a single criterion for optimality. For hierarchical systems, each of the subsystems has its own local criteria [7]. 
Typical examples of the object of research are technological audit of hierarchical control systems of integrated energy systems, transport systems, communication systems, and industrial complexes.

\section{The aim and objectives of research}

The aim of research is to provide information analysis of modeling methods for complex economic systems under conditions of uncertainty and risk.

To achieve this aim, the following tasks are formulated:

1. To conduct a comprehensive analysis of the description of the processes of functioning of complex economic systems.

2. To carry out a comprehensive analysis of the state of scientific and methodological support for managing the information potential of complex economic systems, taking into account a risk.

3. To conduct a comprehensive analysis of levels and approaches to the management of production hierarchical systems.

4. To give recommendations on the use of different types of mathematical tools for modeling the management of the information potential of complex economic systems under conditions of risk.

\section{Research of existing solutions of the problem}

Researches of methods for modeling of the management of production systems in conditions of uncertainty are of practical interest. In [7, 8], the state of approaches and procedures for selecting managerial decisions is analyzed in terms of preferences and limitations of one or a number of variants with known or unknown reaction of the environment, in the form of points of a payment matrix. The location of the selected maximum element determines the decision-making option. The authors of $[9,10]$ investigate the problems of situational control under conditions of multicriteria logic. Decision making is achieved by obtaining an outcome that has the highest possible score for each of the criteria. The essence, content, functioning of complex systems and management of information potential in conditions of uncertainty to describe a situation that do not have strictly defined boundaries is analyzed in $[11,12]$.

The implementation of decision-making tasks under uncertainty is made by constructing a generalized criterion that synthesizes a set of estimates according to specified particular criteria into a single numerical estimate expressing the overall utility of management. Structuring of the set of control alternatives under uncertainty conditions using the theory of fuzzy sets is reflected in [12, 13]. Decision-making is based on probabilistic ideas about ongoing processes. Determination of the special role of modeling the management of the information potential of complex economic systems under conditions of risk at the present stage of development of the Ukrainian economy is devoted the work [14, 15], which consists in the decomposition of the problem and the phased establishment of priorities. The technique is designed to analyze nonlinear structures when considering a variety of factors, taking into account the dependencies and feedbacks between them.
In the theory of modeling the management of the information potential of complex economic systems under conditions of risk, numerous methods and algorithms [2, 4, 8, 14] are found for finding points of the global extremum of functions of several variables for various particular cases. However, no general methods for finding extrema were found. Finding the target functions of mathematical models provides for the optimality of existing constraints on available resources, possible boundaries for their variation and the choice of more precise methods for their implementation.

\section{Methods of research}

The development of methods and models of strategic management of production facilities in the context of information uncertainty used the main provisions of the theory of systems [2, 4]. In the process of research, methods of abstractions and analogies were used to deepen the concepts of multicriteria choice, system analysis in the formation of an information management system, theory of sets and hierarchical structures when formalizing the management problem under uncertainty and risk.

\section{Research results}

Management of complex economic systems requires constant research, as in the current economic conditions the situation is constantly changing, which requires identifying pressing problems and determining the prospects for development.

Changes in the volume of macroeconomic indicators, including calculations of labor productivity and average wages are presented in Table 1 [16].

Analysis of the data of Table 1 makes it possible to conclude on the dynamics of the volume of macroeconomic indicators. There is a positive dynamics of growth in gross domestic product. It should be noted that in 2014, compared to 2009, GDP increased by $72 \%$ and in 2015 by $117 \%$. Labor productivity increased by $103 \%$ in 2014 and in 2015 by $166 \%$ compared with 2009 , and the average monthly wage by $83 \%$ and $120 \%$, respectively. The average inflation rate exceeded the $10 \%$ limit. In 2011, the inflation rate increased by $112.9 \%$, in 2014 it was $124.9 \%$, in 2015 it was $143.3 \%$.

Wages in Ukraine are among the lowest in the world. Table 2 presents data on the minimum hourly rate in different countries at the end of 2016 [17].

Analyzing Table 2, it is advisable to conclude that this is due to the difficult financial, economic, political and social state of the country.

In accordance with the data of Table 1 and Table 2, it can be concluded that cheap labor can't efficiently and effectively affect the economy and rational use of productive resources, increase the technical level of production, improve product quality. The solution of this problem is possible due to the revival and development of production, increase of its efficiency on the basis of wide use of new technology, science achievements and modeling of management of the information potential of complex economic systems under risk. This type of management is advisable to use in forecasting economic indicators of the development of complex multi-level systems. This gives additional opportunities in the effective definition of the targets for the development of economic systems. 
Dynamics of macroeconomic indicators of the Ukrainian economy

\begin{tabular}{|c|c|c|c|c|c|c|c|}
\hline Indicators & 2009 & 2010 & 2011 & 2012 & 2013 & 2014 & 2015 \\
\hline Gross domestic product in actual prices, mln. UAH & 912563 & 1082569 & 1316600 & 1408889 & 1465198 & 1566798 & 1979485 \\
\hline Gross domestic product in constant prices in 2009, mln. UAH & 787371 & 934054 & 1135979 & 1215607 & 1264192 & 1351853 & 1707925 \\
\hline Number of employees, thousand people & 20191.5 & 20266 & 20324.2 & 19261.4 & 19314.2 & 18073.3 & 16443.2 \\
\hline $\begin{array}{l}\text { Labor productivity in actual prices (average monthly workings), thous. } \\
\text { UAH/person }\end{array}$ & 45197 & 53418 & 64780 & 73146 & 75861 & 86691 & 120383 \\
\hline $\begin{array}{l}\text { Labor productivity in constant prices in } 2009 \text { (average monthly workings), } \\
\text { thousand UAH/person }\end{array}$ & 38995 & 46090 & 55893 & 63111 & 65454 & 74798 & 103868 \\
\hline $\begin{array}{l}\text { The index of changes in labor productivity in comparison with the last } \\
\text { year in actual prices, \% }\end{array}$ & - & 118 & 121 & 113 & 104 & 114 & 139 \\
\hline The index of changes in labor productivity in comparison with $2009, \%$ & 100 & 118 & 143 & 162 & 168 & 192 & 266 \\
\hline Average monthly nominal wage, UAH & 1906 & 2239 & 2633 & 3025 & 3282 & 3480 & 4195 \\
\hline $\begin{array}{l}\text { Ratio of growth rates of average monthly wages and labor productivity } \\
\text { in actual prices, \% }\end{array}$ & 1.00 & 1.00 & 0.975 & 1.018 & 1.038 & 0.930 & 0.867 \\
\hline $\begin{array}{l}\text { Ratio of growth rates of average monthly wages and labor productivity } \\
\text { in constant prices (2009), \% }\end{array}$ & 1.00 & 1.00 & 0.965 & 0.982 & 1.024 & 0.953 & 0.827 \\
\hline The minimum wage, UAH & 744 & 922 & 1004 & 1134 & 1218 & 1218 & 1378 \\
\hline Index of the minimum wage, \% & - & 123.9 & 108.9 & 112.9 & 107.4 & 100.0 & 113.1 \\
\hline Inflation rate, $\%$ & 112.3 & 109.1 & 104.6 & 100.0 & 100.5 & 124.9 & 143.3 \\
\hline Average annual growth rate of inflation, \% & 115.9 & 109.4 & 108.0 & 100.6 & 99.7 & 112.1 & 148.7 \\
\hline The growth of inflation in comparison with 2009, \% & 100 & 97 & 93 & 89 & 90 & 111 & 128 \\
\hline
\end{tabular}

Table 2 problems and the identification of other related problems,

Hourly minimum wage in the countries of the world

\begin{tabular}{|c|c|}
\hline Country & Wage rate, USD/hour \\
\hline France & 10.4 \\
\hline Germany & 9.4 \\
\hline United Kingdom & 11.1 \\
\hline Poland & 2.6 \\
\hline Spain & 4.7 \\
\hline Turkey & 6.5 \\
\hline Israel & 6.5 \\
\hline Russia & 0.5 \\
\hline China & 1.4 \\
\hline Japan & 6.9 \\
\hline Indonesia & 1.1 \\
\hline India & 0.7 \\
\hline Taiwan & 3.6 \\
\hline South Когеа & 5.2 \\
\hline Colombia & 1.0 \\
\hline Brazil & 1.0 \\
\hline Canada & 8.4 \\
\hline USA & 7.3 \\
\hline Australia & 12.3 \\
\hline Ukraine & 0.28 \\
\hline
\end{tabular}

The structural-functional sequence of operations for managing multi-level hierarchical systems is shown in Fig. 1.

The main determining factor in the analysis of the problem situation is the establishment of the causes of its occurrence. When identifying the problem and the ways to solve it, one should take into account the expansion of without regard to which it can't be solved.

The variety of the physical nature of subsystems entering into a complex control system and solved problems leads to the need for their study at various levels of abstract description: linguistic, heuristic, information and mathematical (Fig. 2).

The main goal of the linguistic level of the abstract description of functioning processes of a complex economic system is to establish its content.

The heuristic aspect of the structuring of management systems of multi-level hierarchical systems is to establish, form and aggregate the criteria for optimality. The most important criteria for the effectiveness of economic systems are: profit, production costs, production volumes, and competitiveness. Especially the heuristic aspect of management is manifested in the use of methods of expert assessments. It is based on the fact that the determined characteristic of a production facility is considered a random variable. Its true meaning and distribution law are determined by each expert individually.

Information aspect of managing multi-level hierarchical systems is represented by the following sequence of actions.

In a multi-level hierarchical control system, the upper level subsystem coordinates the operation of lower level subsystems using control actions $I_{j} \in I$ determined by their optimality criterion, and each subsystem of the lower level searches for its own control actions according to its optimality criteria, taking into account resource constraints.

Criteria of optimality of upper level subsystems may not reach their optimal value when choosing control actions taking into account the criteria of subsystems of the lower level. This makes it necessary to clarify the interactions of subsystems of different levels among themselves and establish compromise values of the criteria. 


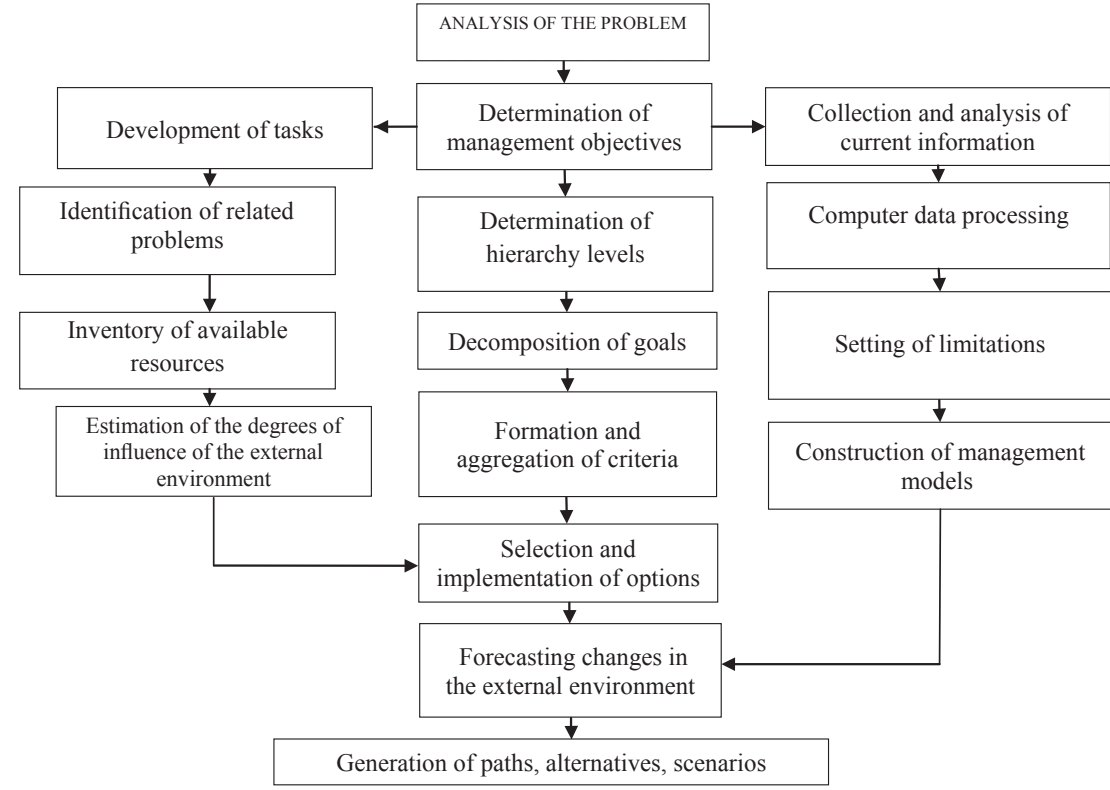

Fig. 1. Structural and functional sequence of operations for management of multi-level hierarchical systems
The technical and economic characteristics of this variant will be denoted by $g_{i}(v), g_{i}(v) \geq 0$. The quantitative values of these characteristics in the general spectrum of solved problems are determined by the capabilities and resources $[2,6]$. The available resource level of the selected control option for i-th characteristic of the system is denoted by $g_{i}^{*}$. This parameter is characterized by its minimum possible and maximum allowed values, which is displayed by indices $i=\overline{1, n}, n \leq N$ for the upper level and $i=\overline{n+1, N}$ for the lower level.

Taking into account the introduced designations, the maximum possible resource that can be allocated to these subsystems from the total amount of resources allocated for the entire system as a whole can be expressed in the form of the following system of equations and inequalities:

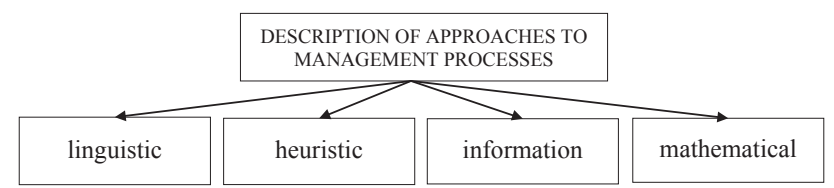

Fig. 2. Structuration of approaches to management of hierarchical systems

The choice of control actions, taking into account the interactions of the lower levels of the hierarchy of possibilities and reactions to these disturbances, is a multicriteria problem of mathematical programming [4] and reduces to making a decision on a set of criteria $f=\left\{f_{i}\left(U_{i}\right), i \in I\right\}, I=\overline{0, M}$. In this form of record, zero corresponds to the number of the criterion of the upper level subsystem.

Information component of management of hierarchical economic systems distinguishes:

- the existence of priorities in decision-making between

levels of the hierarchy;

- location and ranking of managed subsystems in relation to the priorities of decisions;

- coordination of interactions;

- formation of parameters of management models;

- selection of the most promising types of management, taking into account modern business conditions and restrictions on production resources.

The mathematical description of management is connected with formalization of the main solved problems and choice of the optimal variant.

Conclusions obtained by using mathematical tools and modeling complex economic systems make it possible to find previously unknown characteristics of complex systems, their structure, dynamics of development, stability of integrity, and S - working capacity state of the elements of the system.

The analytical description of these quantities is made at the formal logical level and is the basis for implementing the temporary iterative refinement of the tolerances for resources and the influence of the external environment.

The reliability index of the chosen variant of the system $v \in V^{n}$ will be denoted by $p(v)$, then $0 \leq p(v) \leq 1$.

$$
\begin{aligned}
& p(v) \rightarrow \max ; \\
& g_{i}(v) \leq g_{i}^{*}, i=\overline{1, n} ; \\
& g_{i}(v) \leq g_{i}^{*}, i=\overline{n+1, N} ; \\
& v=\left(v_{1}, \ldots, v_{j}, \ldots, v_{M}\right) \in V^{n}=\prod_{j=1}^{M} U_{j} .
\end{aligned}
$$

Here $p, g_{1}-$ the functions of a discrete argument.

The so-called sequential systems have a multiplicative reliability function. A failure in any subsystem $k$ in these systems leads to the failure of the entire system as a whole [2]. In this case, private failures don't affect each other. In this case:

$$
p(v)=\prod_{j=1}^{M} p_{i}\left(v_{j}\right) .
$$

This means that in order to ensure the reliability of the operation of production economic systems, it is necessary to choose a management alternative $v_{j}^{n} \in V^{n}$ in such a way as to ensure the successful solution of all tasks posed to the system with probabilities of failure-free operation of not less than specified levels $p_{k}^{*}, k=\overline{1, n}$.

Taking into account the reliability of the management system, the general mathematical model is transformed as follows:

$$
\begin{aligned}
& p(v)=\prod_{j=1}^{M} p_{j}\left(v_{j\left(I_{j}\right)}\right) \rightarrow \max ; \\
& p_{k}(v)=\prod_{j \in L_{k}} p_{j}\left(v_{j\left(I_{j}\right)}\right) \geq p_{k}^{*}, k=\overline{1, r} ; \\
& g_{i}(v)=\prod_{j=1}^{M} g_{i_{j}}\left(v_{j\left(I_{j}\right)}\right) \leq g_{i}^{*}, i=\overline{1, n} ; \\
& v=\left(v_{1}, \ldots, v_{j}, \ldots, v_{M}\right) \in V^{n}=\prod_{j=1}^{M} U_{j},
\end{aligned}
$$


where $L_{k}$ - the general subset of the statistical failures of the subsystem.

Situations described by mathematical models, in practice, may not be fully adequate to reality, since the implementation of the model assumes multiple repetitions of actions undertaken under similar conditions. In reality, the number of decisions taken under unchanged conditions is severely limited.

Modeling of management of complex economic systems is carried out at the formal and logical level by sequential localization of the spatial partitioning of the system's options into groups of subsystems that are detailed on the set of analyzed elements.

The scheme for modeling complex economic systems based on the above-mentioned information is presented in Fig. 3.

The goal of the described mathematical toolkit for modeling complex economic systems consists in the integrated use of information analysis and synthesis of processes of constructing the interaction of structural control components and the possibility of using application software. The choice of the sequence of operation in the proposed mathematical tool depends on the results of modeling the previous steps. The use of the described approaches to the management of multi-level hierarchical systems and their specific sequence are determined by the specifics of the conditions for realizations.

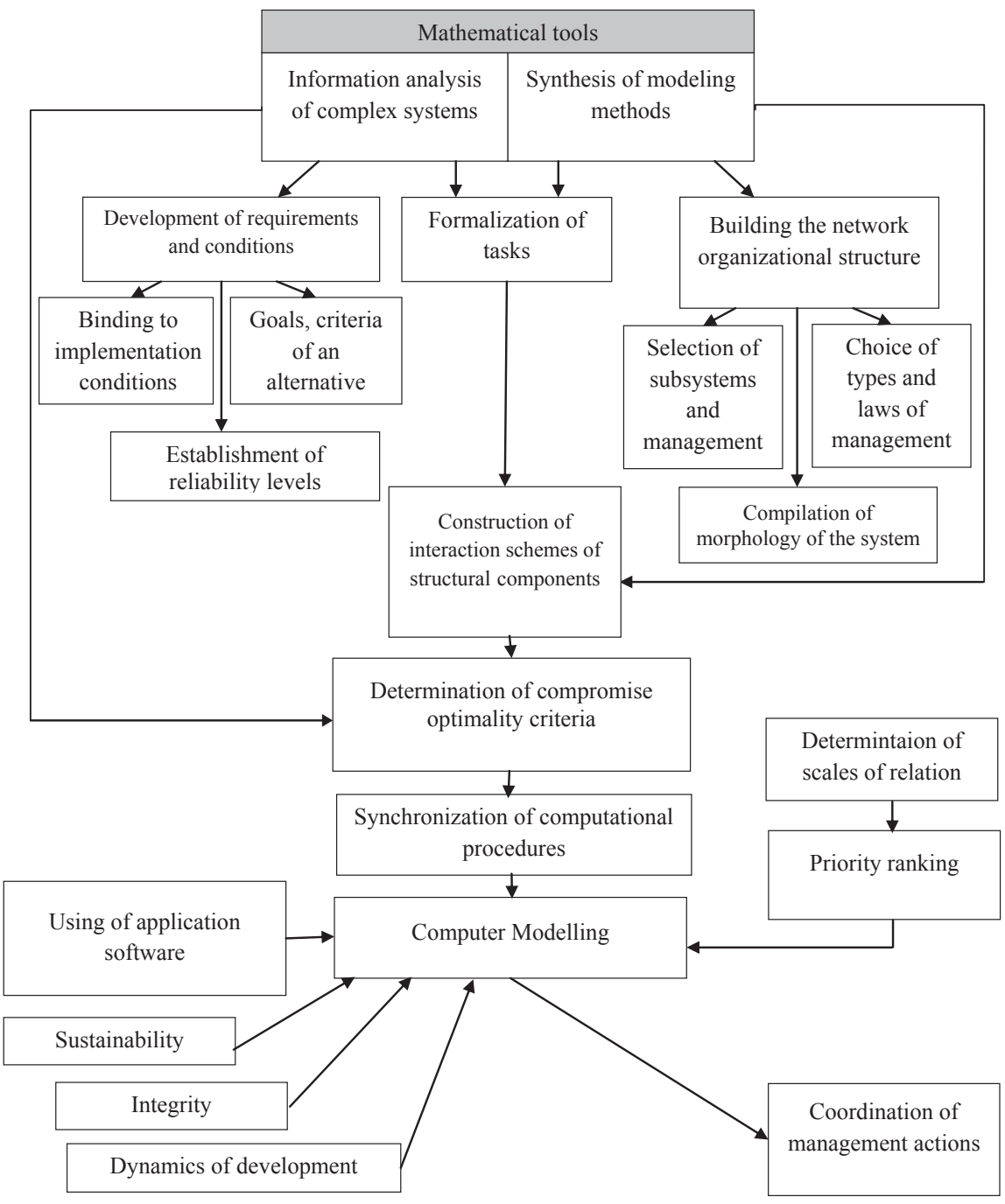

Fig. 3. Modeling of the management of complex economic systems

\section{SWOT analysis of research results}

Strengths. The strength of this research compared with analogues is the orientation to the interactive mode of operation, in which all management procedures at any time and space point are detailed on the set of elements, taking into account limitations and resource capabilities. At the same time, the search for variants lying in the range of the objective function change is carried out, and many elements of the technical implementation are specified.

Weaknesses. The weak side is that the data on all types of information potential management are not always objective, since dynamic changes in the external environment of the functioning of complex economic systems are constantly changing, which makes it difficult to forecast them in conditions of uncertainty and risk.

Opportunities. The opportunity of further research is the use of the experience of foreign countries to improve the modeling of information management of complex economic systems under conditions of risk.

Threats. Threats to use the results of conducted research on information analysis and the synthesis of processes occurring in complex economic systems characterized by multifunctionality and the variety of options for the structure of relations are limiting restrictions on resources. Influence on the information potential of external factors, such as the revision of the company's budget, the socio-economic instability of the country and the deepening of the global financial crisis affects the reduction or increase of information indicators.

\section{Conclusions}

1. The conducted researches on management modeling by information potential of difficult economic systems under conditions of risk testify to an unstable situation in modern conditions of manufacture functioning. There is a generally positive dynamics of the variety of options for the structure of relations occurring in complex economic systems. The predicted positive dynamics of the complication of production relations, especially in the context of globalization and European integration, will increase steadily.

2. Comprehensive analysis of the state of scientific and methodological support of information risk management allowed to prove the development of mathematical tools based on information analysis of complex systems and the synthesis of modeling methods as a promising direction in managing the development of economic systems.

3. A comprehensive analysis of levels and approaches to the management of production hierarchical systems showed that the linguistic 
level is recommended to be used at the initial stage of determination of a meaningful management interpretation. The heuristic level is recommended for expert assessments of the characteristics of production facilities, information when clarifying the interactions of control subsystems, mathematical - for formalizing the solved tasks and choosing the best option.

4. Recommendations on the use of different types of mathematical tools for modeling of the management of information potential under conditions of risk are: in the structuring of the problem, in formulating the main tasks, the list of basic control elements, describing the main parameters that determine the functioning of the system, determination of output variables; in system analysis in the formation of a database and information management system; in decomposition - in the division of decision-making functions in complex control systems; in multi-criteria optimization in the selection of criteria characterizing the properties controlled by the production system; in the synchronization of computing and information processes; in linear programming in evaluating the reactions of lower control levels to the control action of the upper levels; in the construction of a morphological block of management of a complex economic system, taking into account possible implementation options, difficulties and limiting restrictions.

The conducted researches on modeling of management of information potential of difficult economic systems under conditions of risk allowed to develop mathematical management tools on the basis of information analysis of complex systems and synthesis of modeling methods, as well as to give practical recommendations on the integrated use of management levels and approaches under uncertainty.

\section{References}

1. Mikoni, S. V. Mnogokriterial'nyi vybor na konechnom mnozhestve al'ternativ [Text] / S. V. Mikoni. - St. Petersburg: Lan, 2009. - 272 p

2. Voloshin, A. F. Posledovatel'nyi analiz variantov v zadachah issledovaniia i proektirovaniia slozhnyh sistem [Text]: Monograph / A. F. Voloshin, V. I. Kudin. - Kyiv: Kievskii universitet, 2015. - $351 \mathrm{p}$

3. Sharko, M. V. Formalizatsiia parametrov tsennostno-orientirovannogo upravleniia razvitiem promyshlennogo proizvodstva [Text] / M. V. Sharko // Visnyk Lvivskoi komertsiinoi akademii. - 2015 - Vol. 49. - P. 105-109.

4. Zaichenko, Yu. P. Mnogokriterial'nye zadachi priniatiia reshenii $\mathrm{v}$ nechetkih usloviiah [Text] / Yu. P. Zaichenko, O. Yu. Zaichenko // Pratsi VIII Mizhnarodnoi shkoly seminaru «Teoriia pryiniattia rishen». - Uzhhorod UzhNU, 2016. - P. 121-122.

5. Sharko, M. V. Kommertsializatsiia intellektual'noi sobstvennosti pri transfere tehnologii $\mathrm{v}$ real'nyi sektor ekonomiki [Text] M. V. Sharko // Problemy ekonomiky. - 2015. - № 1. P. $168-173$

6. Sharko, M. V. Formirovanie politiki narashchivaniia intellektual'nogo potentsiala [Text] / M. V. Sharko, Yu. V. Panchenko // Aktualni problemy ekonomiky. - 2014. - № 6 (156). - P. 30-40.

7. Fiser, J. Representation of System Level Self-Diagnosis in Python Programming Language [Text] / J. Fiser, V. Mashkov, V. Lytvynenko // Electrotechnic and Computer Systems. - 2015. № 17 (93). - P. 48-54.

8. Mashkov, V. Development issues in algorithms for system level self-diagnosis [Text] / V. Mashkov, A. Smolarz, V. Lytvynenko // Informatics, Control, Measurement in Economy and Environment Protection. - 2016. - Vol. 6, № 1. - P. 26-28. doi:10.5604/20830157.1194261
9. Baldi, P. the dropout learning algorithm [Text] / P. Baldi, P. Sadowski // Artificial Intelligence. - 2014. - Vol. 210. P. 78-122. doi:10.1016/j.artint.2014.02.004

10. Gupta, M. An algorithmic approach to group decision making problems under fuzzy and dynamic environment [Text] / M. Gupta, B. K. Mohanty // Expert Systems with Applications. 2016. - Vol. 55. - P. 118-132. doi:10.1016/j.eswa.2016.02.002

11. André, É. Parameter synthesis for hierarchical concurrent realtime systems [Text] / É. André, Y. Liu, J. Sun, J.-S. Dong // Real-Time Systems. - 2014. - Vol. 50, № 5. - P. 620-679. doi:10.1007/s11241-014-9208-6

12. Guangyan, L. Assessment on Reform Solution of Enterprise Management and Control Model Based on Group Hierarchy Grey Method [Text] / L. Guangyan, L. Peishun, L. Xiaofeng, X. Caiping // Procedia Engineering. - 2012.- Vol. 37.- P. 42-48. doi:10.1016/j.proeng.2012.04.199

13. Savina, G. Estimation of the Effectiveness and Functioning of Enterprises in Boards of Corporate Security [Text] / G. Savina, S. Kavun, D. Caleta, M. Vrsec // European Journal of Scientific Research. - 2013. - Vol. 104, № 2. - P. 304-323.

14. Pankratova, N. System evaluation of engineering objects operating taking into account the margin of permissible risk [Text] / N. Pankratova, L. Kondratova // Eastern-European Journal of Enterprise Technologies. - 2016. - № 3/4 (81). - P. 13-19. doi:10.15587/1729-4061.2016.71126

15. Ruffino, D. Fictions and Risky Corporate Debt [Text] / D. Ruffino, J. Treussard // Economic Notes. - 2007. - Vol. 36, № 1. - P. 77-87. doi:10.1111/j.1468-0300.2007.00172.x

16. State Statistics Service of Ukraine [Electronic resource]. Available at: \www/URL: http://www.ukrstat.gov.ua

17. Federal State Statistics Service [Electronic resource]. - Available at: \www/URL: http://www.gks.ru/wps/wcm/connect/ rosstat main/rosstat/ru/statistics/icstatistics/incomparisons/\#

\section{МОДЕЛИРОВАНИЕ УПРАВЛЕНИЯ ИНФОРМАЦИОННЫМ ЛОТЕНЦИАЛОМ СЛОЖНЫХ ЭКОНОМИЧЕСКИХ СИСТЕМ В УслОВИЯХ РИСКА}

Проведен информационный анализ и синтез процессов, происходящих в сложных экономических системах, характеризуемых многообразием вариантов структуры отношений. Рассмотрена структура управления иерархическими системами с использованием лингвистического, эвристического, информационного и математического подходов. Представлена структурно-функциональная последовательность операций управления с учетом ограничений на ресурсы и влияний внешней среды.

ключевые слова: экономические системы, управление информационными возможностями, условия риска, информационный потенциал.

Sharko Margarita, Doctor of Economic Sciences, Professor, Head of Department, Department of Economics and Entrepreneurship, Kherson National Technical University, Ukraine,e-mail: sharko-8@mail.ru, ORCID: http://orcid.org/0000-0003-2321-459X

Burenko Juliya, PhD, Associate Professor, Department of Economics and Entrepreneurship, Kherson National Technical University, Ukraine, e-mail: burenko-05@mail.ru, ORCID: http://orcid.org/ 0000-0003-0005-7931

Gusarina Nataliya, PhD, Associate Professor, Department of Economics and Organization of Production, National University of Shipbuilding, Mykolayiv, Ukraine, e-mail: gusarina@ukr.net, ORCID: http://orcid.org/0000-0003-3418-9422 